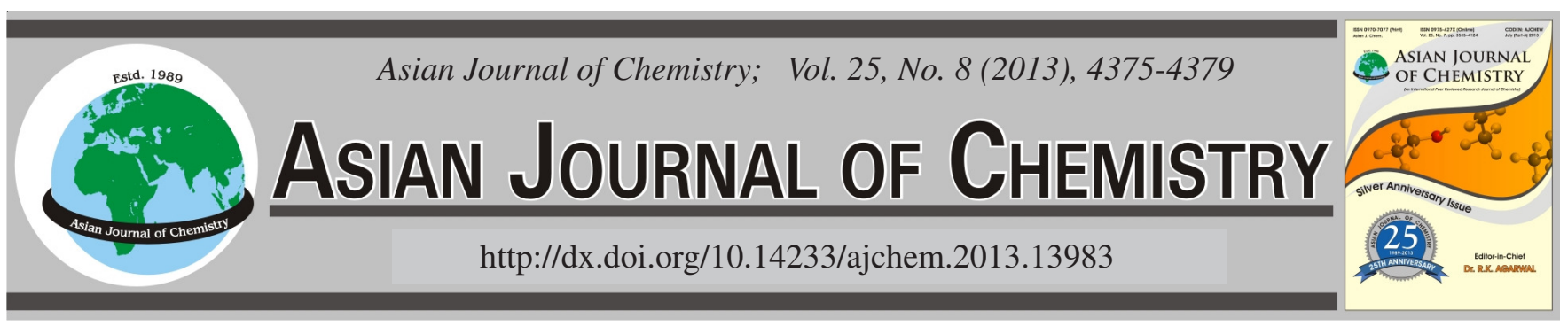

\title{
Electrochemical DNA Biosensor Improved by Imidazo[4,5-f]1,10-phenanthroline Iron(III) as an Indicator based on Pt-nanoparticles and Carbon Nanotubes Modified Electrode
}

\author{
SHU-YAN NiU*, YING-QIANG QIN and BIN HAN
}

Key Laboratory of Eco-chemical Engineering, Ministry of Education, College of Chemistry and Molecular Engineering, Qingdao University of Science and Technology, Qingdao 266042, P.R. China

*Corresponding author: Fax: +86 532 84023927; Tel: +86 532 84022750; E-mail: wenzhangggg@126.com

(Received: 27 April 2012;

Accepted: 11 February 2013)

AJC-12968

A novel and sensitive electrochemical DNA biosensor has been developed for the detection of DNA hybridization. The biosensor was proposed by using imidazo[4,5-f]1,10-phenanthroline iron(III) $\left(\mathrm{Fe}(\text { phen })_{2} \mathrm{IP} \cdot 3 \mathrm{ClO}_{4} \cdot 2 \mathrm{H}_{2} \mathrm{O}\right.$, abbreviated as $\left.\left[\mathrm{Fe}(\text { phen })_{2} \mathrm{IP}\right]^{3+}\right)$, as an electroactive indicator based on multi-walled carbon nanotubes/platinum nanoparticles (MWCNTs/Ptnano) modified glassy carbon electrode (GCE). The interaction between $\left[\mathrm{Fe}(\mathrm{phen})_{2} \mathrm{IP}\right]^{3+}$ and double-stranded DNA (dsDNA) was investigated by cyclic voltammetry (CV). The experiment results showed that $\left[\mathrm{Fe}(\mathrm{phen})_{2} \mathrm{IP}\right]^{3+}$ presented an excellent electrochemical activity on GCE and could intercalate into the double helix of double-stranded DNA. The target ssDNA of the human hepatitis B virus (HBV) was quantified in a linear range from $1.13 \times 10^{-11}-1.13 \times$ $10^{-9} \mathrm{M}(\mathrm{r}=0.9892)$ with a detection limit of $5.56 \times 10^{-12} \mathrm{M}(3 \sigma, \mathrm{n}=11)$.

Key Words: $\mathrm{Fe}(\text { phen })_{2} \mathrm{IP} \cdot 3 \mathrm{ClO}_{4} \cdot 2 \mathrm{H}_{2} \mathrm{O}$, Carbon nanotubes, Pt-nanoparticles, DNA Hybridization, Electrochemical DNA biosensor.

\section{INTRODUCTION}

In recent years, DNA biosensor has become more and more important, particularly with the advances in genetics, criminology, pathology, pharmacogenetics, food safety and many other fields. Due to its intrinsic specificity, the hybridization between complementary single-stranded DNA (ssDNA) chains has been used as a bio-recognition event in the design of a great number of DNA biosensors. This recognition event has been applied in various ways, such as optical, mechanical or electrochemical ${ }^{1,2}$. Compared to other methods, electrochemical DNA biosensors are attractive devices for their abilities of converting DNA hybridization event into an analytical electronic signal to obtain sequence-specific information and are applied in clinical, environmental or forensic investigations ${ }^{3}$. While immobilization of DNA probes onto the electrode surface has always been the focus of the preparation of electrochemical DNA biosensors. DNA can be immobilized on sensor surfaces with methods similar to those used for enzyme-based biosensors: adsorption, covalent immobilization and avidin (or streptavidin) biotin interaction ${ }^{4}$. Many workers have studied the immobilization of DNA on electrodes surfaces by a wide variety of methods ${ }^{5}$. Recently, the modification of electrochemical sensors with carbon nanotubes (CNTs) has attracted considerable attention in the field of DNA sensing technology, because such modification can drastically improve the effective surface area of the electrodes and carbon nanotubes are rather chemically stable and well conductive, so that carbon nanotubes-modified electrodes always show high performance in electrochemical analysis, especially high sensitivity. Many different schemes for electrochemical DNA sensing based on carbon nanotubes have been reported ${ }^{6-10}$.

Many attempts have been conducted to deposit various metal particles, such as platinum, palladium, copper, nickel or ruthenium, on the surface of carbon nanotubes ${ }^{11-13}$. The hybrid materials could potentially display the combined properties of nanocrystals and carbon nanotubes and also additional novel properties ${ }^{14-16}$ to increase the sensitivity.

On the other hand, the binding mechanisms between DNA and various redox substances, namely metal complexes ${ }^{17,18}$, anticancer or antivirus drugs ${ }^{19}$ and organic dyes ${ }^{20,21}$, have been extensively investigated. In our laboratory, many efforts were also conducted to explore the interaction between metal complexes and $\mathrm{DNA}^{22-23}$. It has been found that phenanthroline based metal complex has a wide range of biochemical and pharmacological effects including antioxidation, antiinflammation, antiplatelet, antithrombotic action and antiallergic effects, which is widely used as the intercalators for its planar structure $^{24-26}$.

In this piece of work, carboxyl-functionalized multiwall carbon nano-tubes (MWCNTs-COOH) modified with $\mathrm{Pt}$ nanoparticles and $\mathrm{Fe}(\text { phen })_{2} \mathrm{IP} \cdot 3 \mathrm{ClO}_{4} \cdot 2 \mathrm{H}_{2} \mathrm{O}$ were utilized in 
the DNA electrochemical biosensor. Pt nanoparticles was combined to the MWCNTs-COOH with the help of nafion by electrostatic force. Oligonucleotide probes with an amino group at the 5'-phosphate end can form covalent bonds with the Pt nanoparticles on the MWCNT-COOH/ $/ t_{\text {nano }} / \mathrm{GCE}$ modified GCE. A phenanthroline base complex, imidazo [f]1,10phenanthroline ferrum(III) ([Fe(phen) $\left.\left.)_{2} \mathrm{IP}\right] \cdot 3 \mathrm{ClO}_{4} \cdot 2 \mathrm{H}_{2} \mathrm{O}\right)$ has been synthesized and characterized used as an indicator for the detection of hybridization between the probe DNA and the target sequence. This novel sensor and the related procedure would be of lower cost and more convenience compared to many DNA sensors developed in the past decade while still possess relatively high selectivity and sensitivity.

\section{EXPERIMENTAL}

Multi-walled carbon nanotubes (with a diameter of about 40-60 nm and length of around 1-10 $\mu \mathrm{m}$ ) with carboxylic groups were obtained from Shenzhen Nanotech Co. Ltd. (Shenzhen, China). Nafion-perfluorinated ion-exchange resin (5 wt. \%), sodium dodecyl sulfate (SDS) and 1-ethyl-3-(3dimethylaminopropyl)carbodiimide solution (EDC) and $\mathrm{N}$ hydroxysuccinimide solution (NHS) were purchased from Sigma. Salmon sperm DNA was purchased from Shanghai Huashun Biological Engineering Company $\left(\mathrm{A}_{260} / \mathrm{A}_{280}>1.8\right)$, the concentration was determined by the ultraviolet absorption at $260 \mathrm{~nm}\left(\varepsilon=13200 \mathrm{M}^{-1} \mathrm{~cm}^{-1}\right)$.

24-Base synthetic ssDNA were purchased from SBS Genetech Company (Beijing China): 24-base probe sequence(S1): 5'-NH2-GAG CGG CGC AAC ATT TCA GGT CGA-3'. Target sequence(S2): 5'-TCG ACC TGA AAT GTT GCG CCG CTC-3' a non-complementary sequence (S3): 5'-GAG CGG CGC AAC ATT TCA GGT CGA-3'.

All ssDNA were dissolved in TE buffer $(10 \mathrm{mM}$ tris $-\mathrm{HCl}$, 1 mM EDTA, pH8.0) and kept frozen. Other chemicals employed were all of analytical reagent grade and deionized water was used throughout the experimental work.

The cyclic voltammetric and differential pulse voltammetric measurements were performed with a CHI 832 electrochemical analyzer (Shanghai Chenhua Instrument Company, China). The three-electrode system consisted of a glassy carbon working electrode, an $\mathrm{Ag} / \mathrm{AgCl}$ reference electrode (saturated $\mathrm{KCl}$ ) and a counter electrode made of platinum. All electrochemical measurements were conducted in a $10 \mathrm{~mL}$ cell at room temperature. A pHS-3D digital acidometer (Rex Electric Chemical Products Department, Shanghai Precision Scientific Instrument Co. Ltd.) were used.

Synthesized of $\mathbf{F e}(\text { phen })_{2} \mathrm{IP} \cdot 3 \mathrm{ClO}_{4} \cdot \mathbf{2 H}_{2} \mathrm{O}$ : Imidazo[4,5$f][1,10]$ phenanthroline (IP) was synthesized according to literature ${ }^{27}$. A $0.058 \mathrm{~g}$ IP was added to a $12 \mathrm{~mL}$ hot solution dissolved $0.068 \mathrm{~g} \mathrm{FeCl}_{3} \cdot 6 \mathrm{H}_{2} \mathrm{O}$ and $0.100 \mathrm{~g}$ 1, 10-phenanthroline (phen). The mixture was refluxed for $5 \mathrm{~h}$ with continuous stirring, which was then allowed to cool at room temperature. After $1 \mathrm{~mL}$ sodium perchlorate solution $(2.5 \mathrm{M})$ was added, the colour of the solution turned to crimson immediately and solid precipitate appeared. The precipitate was recrystallized from hot water and the crimson crystal of $\left[\mathrm{Fe}(\text { phen })_{2} \mathrm{IP}\right] \cdot 3 \mathrm{ClO}_{4}$. $2 \mathrm{H}_{2} \mathrm{O}$ was obtained finally. Elementary analysis: calc. (found) for [ $\left.\mathrm{Fe}(\text { phen })_{2} \mathrm{IP}\right] \cdot 3 \mathrm{ClO}_{4} \cdot 2 \mathrm{H}_{2} \mathrm{O}: \mathrm{C}: 44.13$ (44.25); $\mathrm{H}: 3.2$ (3.07);
$\mathrm{N}: 11.1$ (11.18). The formula of the $\left[\mathrm{Fe}(\text { phen })_{2} \mathrm{IP}\right]^{3+}$ is shown in Scheme-I.

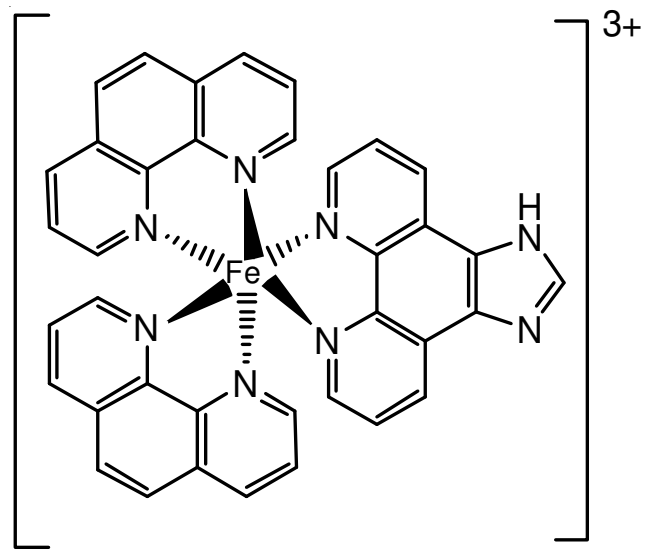

Scheme-I: Structure of $\left[\mathrm{Fe}(\mathrm{phen})_{2} \mathrm{IP}\right]^{3+}$

Preparation of platinum nanoparticles and modification electrode: Platinum nanoparticles $\left(\mathrm{Pt}_{\text {nano }}\right)$ were prepared according to the literature ${ }^{28}$. In brief, $\mathrm{H}_{2} \mathrm{PtCl}_{6} \cdot 6 \mathrm{H}_{2} \mathrm{O}(4 \mathrm{~mL} 5$ $\%$ aqueous solution) was added to deionized water $(65 \mathrm{~mL})$ and heated to $80{ }^{\circ} \mathrm{C}$ with stirring in a $100 \mathrm{~mL}$ flask. After adding $12 \mathrm{~mL}$ of sodium citrate ( $1 \%$ aqueous solution), the resulting solution was maintained at $80 \pm 0.5^{\circ} \mathrm{C}$ for about $4 \mathrm{~h}$. The course of the reduction was followed by absorption spectroscopy and the end of the reaction was marked by the disappearance of the absorption bands of $\mathrm{PtCl}_{6}{ }^{2-}$ (Fig. 1).

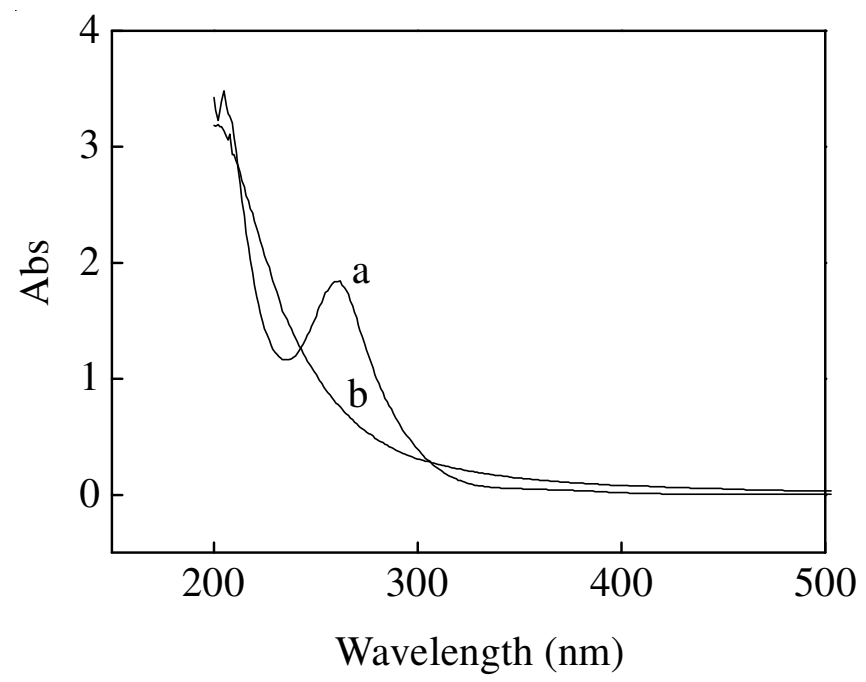

Fig. 1. Absorption bands of $\mathrm{PtCl}_{6}{ }^{2-}$ before (curve a) and after (curve b) reaction

Glassy carbon electrode was carefully polished with polishing paper and subsequently with alumina until a mirror finish was obtained. After 5 min of sonication to remove the alumina residues, the electrode was immersed in concentrated $\mathrm{H}_{2} \mathrm{SO}_{4}$ for 3 min followed by thorough rinsing with water and ethanol. The electrode was then transferred to the electrochemical cell for cleaning by cyclic voltammetry between -0.5 and +1.2 $\mathrm{V}$ (versus $\mathrm{Ag} / \mathrm{AgCl}$ ) in $50 \mathrm{mM}$ phosphate buffer, $\mathrm{pH} 7.2$, until a stable cyclic voltammetric profile was obtained. The prepared electrode was dried and use immediately for modification. An 
amount of $2 \mathrm{mg}$ of MWCNTs were dissolved in a mixture of $100 \mu \mathrm{L}$ of naflon and $900 \mu \mathrm{L}$ of $\mathrm{Pt}_{\text {nano }}$ solution ${ }^{29}$, as the stock solution. After about 40 min of sonication, uniformly dispersed MWCNTs and $\mathrm{Pt}_{\text {nano }}$ were formed. GCE was then modified by a $5 \mu \mathrm{L}$ drop of MWCNTs-COOH/Pt $\mathrm{t}_{\text {nano }}$ and dried in air. After the electrode was thoroughly rinsed with water, the MWCNTs/ $\mathrm{Pt}_{\text {nano }}$-modified electrodes were prepared.

Immobilization of SsDNA on MWCNTs-COOH/Pt nano- $^{-}$ modified GCE: The immobilization of ssDNA probe on the MWCNTs-COOH/Pt $\mathrm{Pano}_{\text {nano }}$ modified GCE was carried out as follows: The MWCNTs-COOH/Pt $\mathrm{Pnn}_{\text {non }}$ modified GCE was immersed in a $30 \mathrm{mM}$ acetate buffer ( $\mathrm{pH}$ 5.2) containing 10 $\mathrm{mM}$ EDC for $1 \mathrm{~h}$. The 1-ethyl-3-(3-dimethylaminopropyl)carbodiimide (EDC)-attached electrode was washed with acetate buffer and subsequently incubated in a $2.25 \times 10^{-5} \mathrm{M}$ oligonucleotide solution containing $0.1 \mathrm{M} \mathrm{EDC}$ and $10 \mathrm{mM}$ acetate buffer $(\mathrm{pH} 5.2)$ for $12 \mathrm{~h}$ with stirring at room temperature. Then the electrode was washed with a $0.2 \%$ sodium dodecyl sulfate phosphate buffer $(\mathrm{pH} 7.3)$ for 5 min to remove the unbound DNA probes and prevent the nonspecific binding. Thus the oligonucleotide probe was immobilized through the formation of amide bonds between the $-\mathrm{COOH}$ on the MWCNTs and $-\mathrm{NH}_{2}$ of the ssDNA at 5' end.

Hybridization and electrochemical detection: Hybridization reaction was carried out by immersing the ssDNA probe captured MWCNTs-COOH/ $/ \mathrm{Pt}_{\text {nano }} / \mathrm{GCE}$ into a stirred hybridization solution ( $0.3 \mathrm{M}$ PBS buffer) containing different concentration of DNA target for $40 \mathrm{~min}$ at $37^{\circ} \mathrm{C}$. After that, the electrode was rinsed three times with a $0.2 \%$ sodium dodecyl sulfate phosphate buffer $(\mathrm{pH} 7.3)$ to remove the nonhybridized target DNA.

Intercalation of hybridization indicator: The accumulation of $\left[\mathrm{Fe}(\mathrm{phen})_{2} \mathrm{IP}\right]^{3+}$ on the hybridized electrode surface was performed by immersing the electrode into $0.20 \mathrm{M} \mathrm{B-R}$ buffer solution ( $\mathrm{pH}$ 5.0) containing $2.0 \times 10^{-4} \mathrm{M}\left[\mathrm{Fe}(\mathrm{phen})_{2} \mathrm{IP}\right]^{3+}$ for $20 \mathrm{~min}$ at room temperature. Then, the electrode was washed with ultrapure water to remove the remnant $\left[\mathrm{Fe}(\text { phen })_{2} \mathrm{IP}\right]^{3+}$ on the electrode surface.

Electrochemical detection: The electrochemical detection of hybridization was performed in a $10 \mathrm{~mL}$ of electrochemical cell with hybridized working electrode, an $\mathrm{Ag} / \mathrm{AgCl}$ electrode and a platinum wire counter electrode. The differential pulse voltammetric measurements were conducted from 0.70-1.2 V (versus $\mathrm{Ag} / \mathrm{AgCl}$ ) in a $0.1 \mathrm{M}$ phosphate buffer $(\mathrm{pH} 7.3)$. The peak current related to the $\left[\mathrm{Fe}(\mathrm{phen})_{2} \mathrm{IP}\right]^{3+}$ at about $+0.94 \mathrm{~V}$ was taken as the electrochemical measurement signal.

The procedure of the operation of the sensor, including the modification of MWCNT/ $\mathrm{Pt}_{\text {nano }}$ immobilization, hybridization and detection of DNA, was illustrated in Scheme-II.

\section{RESULTS AND DISCUSSION}

Cyclic voltammetry study of the interaction between $\left[\mathbf{F e}(\text { phen })_{2} \mathbf{I P}\right]^{3+}$ and dsDNA: Appropriate amount of dsDNA and $\left[\mathrm{Fe}(\mathrm{phen})_{2} \mathrm{IP}\right]^{3+}$ was mixed and incubated in $0.20 \mathrm{M} \mathrm{B-R}$ buffer ( $\mathrm{pH}$ 5.0) for $20 \mathrm{~min}$ at $25^{\circ} \mathrm{C}$. The interaction characterization of $\left[\mathrm{Fe}(\text { phen })_{2} \mathrm{IP}\right]^{3+}$ with dsDNA was performed by cyclic voltammetrics. As to cyclic voltammetric scanning, the potential scanning range was from 1.2 to $0.4 \mathrm{~V}$; the scanning rate was $0.20 \mathrm{~V} \mathrm{~s}^{-1}$; the sample interval was $0.001 \mathrm{~V}$ and the quiet time was $2 \mathrm{~s}$ (Fig. 2). Electrochemical study on $\left[\mathrm{Fe}(\mathrm{phen})_{2} \mathrm{IP}\right]^{3+}$ and its interaction with dsDNA were performed. There were a couple of quasi-reversible redox peaks for $\left[\mathrm{Fe}(\mathrm{phen})_{2} \mathrm{IP}\right]^{3+}$ (curve a). The anodic peak potential $\mathrm{E}_{\mathrm{pa}}=0.949$ $\mathrm{V}$, cathodic peak potential $\mathrm{E}_{\mathrm{pc}}=0.870 \mathrm{~V}$; Curve $\mathrm{b}$ was the

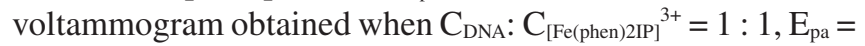
$0.952 \mathrm{~V}, \mathrm{E}_{\mathrm{pc}}=0.876 \mathrm{~V}$; curve $\mathrm{c}$ was the voltammogram obtained when $\mathrm{C}_{\mathrm{DNA}}: \mathrm{C}_{[\mathrm{Fe}(\text { phen)2IP] }}{ }^{3+}=5: 1, \mathrm{E}_{\mathrm{pa}}=0.956 \mathrm{~V}, \mathrm{E}_{\mathrm{pc}}=0.881 \mathrm{~V}$. The peak potential separation $\left(\Delta \mathrm{E}_{\mathrm{p}}\right)$ was $9 \mathrm{mV}$ and its formal potential $\left(\mathrm{E}^{\mathrm{o}}\right)$ was $0.919 \mathrm{~V}$. Pang and $\mathrm{Abruna}^{30}$ had reported the discrimination of binding modes between small molecules and DNA. If $\mathrm{E}^{\mathrm{o}}$ shifted to more negative value, the interaction mode was electrostatic binding. On the contrary, if $\mathrm{E}^{\mathrm{o}}$ shifted to more positive value, the interaction mode was intercalative binding. Therefore, we attributed the interaction between $\left[\mathrm{Fe}(\text { phen })_{2} \mathrm{IP}\right]^{3+}$ and dsDNA to be intercalation.
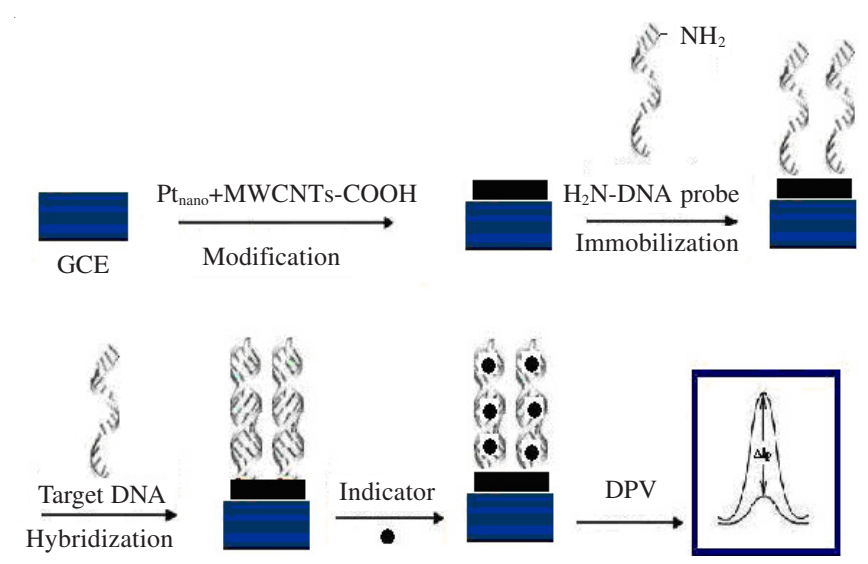

Scheme-II: Schematic representation of the electrochemical detection of DNA hybridization based on platinum nanoparticles combined with MWCNTs

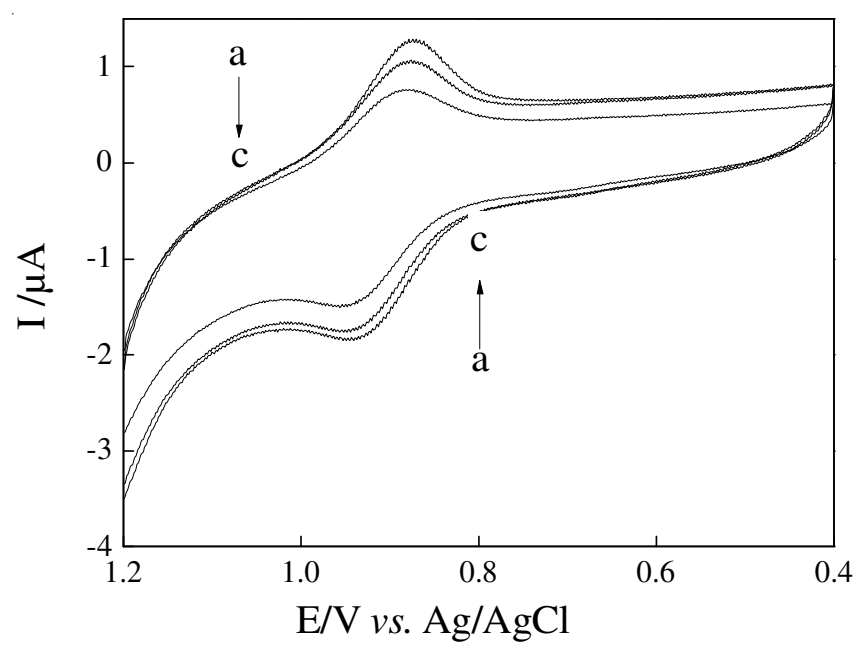

Fig. 2. CVs of $\left[\mathrm{Fe}(\text { phen })_{2} \mathrm{IP}\right]^{3+}$; $\mathrm{C}\left[\mathrm{Fe}(\text { phen })_{2} \mathrm{IP}\right]^{3+}$ : $0.20 \mathrm{mM}$; CDNA: (a) 0, (b) $0.20 \mathrm{mM}$, (c) $1.00 \mathrm{mM}$

Optimization of experimental parameters: The influence of experimental conditions, including the $\mathrm{pH}$ of $0.20 \mathrm{M}$ $\mathrm{B}-\mathrm{R}$ buffer and the reaction time, were explored for optimum analytical performance. $\mathrm{pH} 5$ was adopted because the maximum peak current change (before and after addition of dsDNA) was obtained. After incubation of 20 min the peak 
current reached a constant value, therefore, 20 min was chosen as the reaction time. The hybridization time has also been studied as shown in Fig. 3, which reveals the optimum hybridization time is $40 \mathrm{~min}$.

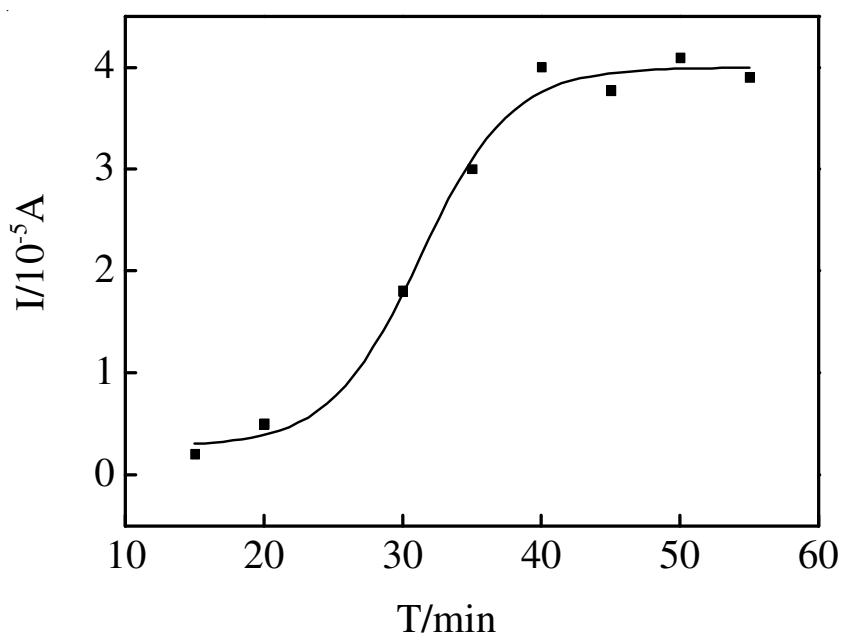

Fig. 3 Effect of the hybridization time on peak current

Electrochemical characteristics of MWCNT-COOH/ $\mathbf{P t}_{\text {nano }} / \mathbf{G C E}$ : Cyclic voltammetry was employed to MWCNT$\mathrm{COOH} / \mathrm{P}_{\text {tnano }} / \mathrm{GCE}$ from 0.6 to $1.1 \mathrm{~V}$. The electrochemical responses of bare GCE (curve a), MWCNTs-COOH/GCE (curve b) and MWCNT-COOH/ $/ \mathrm{Pt}_{\text {nano }} / \mathrm{GCE}$ (curve c) in $2.00 \times$ $10^{-4} \mathrm{M}\left[\mathrm{Fe}(\text { phen })_{2} \mathrm{IP}\right]^{3+}$ were shown in Fig. 4. Compared with the bare GCE and the MWCNT-COOH/ $/ t_{\text {nano }} / \mathrm{GCE}$, the background current of the MWCNTs-COOH/Pt $t_{\text {nano }} / \mathrm{GCE}$ was apparently large, showing that modification of the electrode with MWCNT-COOH/ $/ \mathrm{Pt}_{\text {nano }} / \mathrm{GCE}$ has the best electrical properties while the enlarged electrode surface area could significantly enlarge effective binding for ssDNA.

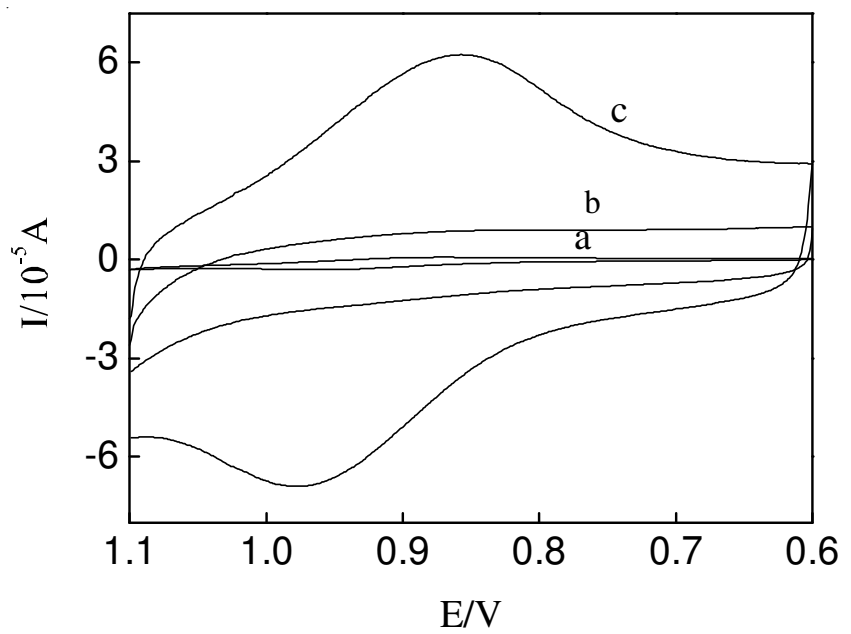

Fig. 4. Cyclic voltammetric curves of $\left[\mathrm{Fe}(\mathrm{phen})_{2} \mathrm{IP}\right]^{3+}$ on different electrodes; (a) GCE; (b) MWCNTs-COOH/GCE; (c) MWCNTs$\mathrm{COOH} / \mathrm{Pt}_{\text {nano }} / \mathrm{GCE}$

Selectivity of the prepared electrochemical DNA biosensor: $\left[\mathrm{Fe}(\text { phen })_{2} \mathrm{IP}\right]^{3+}$ was used as DNA hybridization indicator for the detection of a 24-mer oligonucleotide which is specific for hepatitis B virus and the selectivity of this assay was investigated. The differential pulse voltammetric curves obtained in 0.20 M B-R buffer (pH 5.0) were shown in Fig. 5, on MWCNTs-COOH $/ \mathrm{Pt}_{\text {nano }} / \mathrm{GCE}$ with probe $\operatorname{ssDNA}\left(\mathrm{S}_{1}\right)$ immobilized (curve a), after the hybridization of complementary ssDNA $\left(\mathrm{S}_{2}\right)$ (curve $\mathrm{c}$ ), after the applying of noncomplementary ssDNA $\left(\mathrm{S}_{3}\right)$ (curve b) respectively. Each measurement was performed after $\left[\mathrm{Fe}(\text { phen })_{2} \mathrm{IP}\right]^{3+}$ was sufficiently accumulated and was repeated on at least three GCEs and the mean value of the three closest readouts was adopted as the measurement result. It was found that there was only a small differential pulse voltammetric peak response of $\left[\mathrm{Fe}(\mathrm{phen})_{2} \mathrm{IP}\right]^{3+}$ for $\mathrm{S}_{1}$ modified MWCNTs-COOH/Pt $\mathrm{nano}_{\text {no }} / \mathrm{GCE}$, indicating that only negligible $\left[\mathrm{Fe}(\mathrm{phen})_{2} \mathrm{IP}\right]^{3+}$ was bound to ssDNA $\left(\mathrm{S}_{1}\right)$ on modified MWCNTs-COOH/Pt nano $_{\text {n }} / \mathrm{GCE}$. A significant increase in the differential pulse voltammetric signal was observed after the ssDNA modified MWCNTs-COOH / $\mathrm{Pt}_{\text {nano }} / \mathrm{GCE}$ was hybridized with the complementary ssDNA $\left(\mathrm{S}_{2}\right)$ (curve c). In addition, as expected, there was no significant current difference observed before and after the non-complementary ssDNA $\left(\mathrm{S}_{3}\right)$ was applied on ssDNA probe $\left(\mathrm{S}_{1}\right)$ modified MWCNTs-COOH/ $/ \mathrm{Pt}_{\text {nano }} / \mathrm{GCE}$ (curve $\mathrm{b}$ ), indicating that the non-specific absorption was negligible. A good selectivity was thus obtained for the novel electrochemical DNA biosensor.

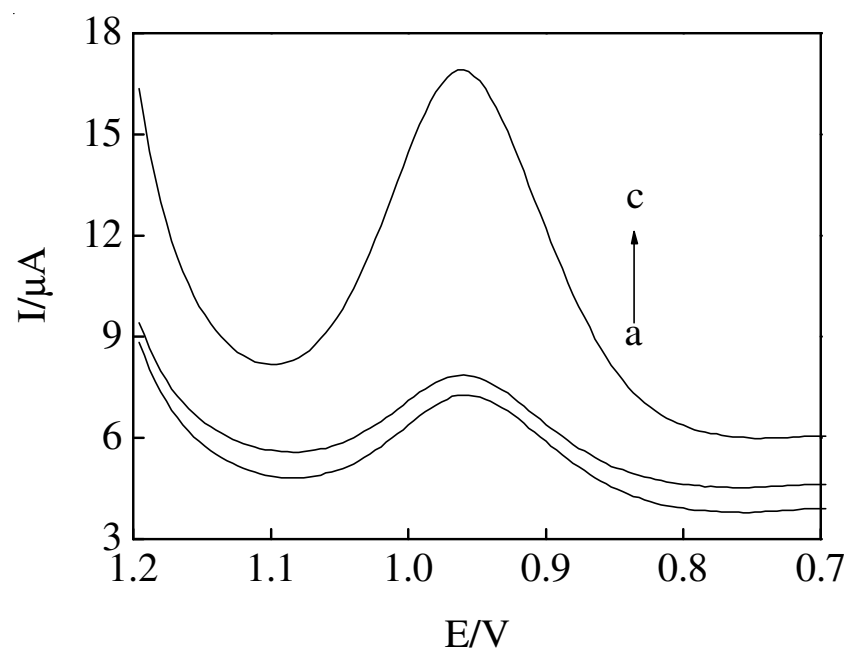

Fig. 5. DPV response of the $\left[\mathrm{Fe}(\mathrm{phen})_{2} \mathrm{IP}\right]^{3+}$ recorded on $\mathrm{MWNTs} / \mathrm{Pt}_{\text {nano }} /$ GCE; (a) probe $\left(\mathrm{S}_{1}\right)$; (b) hybridized with $1.60 \times 10^{-8} \mathrm{M} \mathrm{S}_{3}$; (c) hybridized with $1.60 \times 10^{-8} \mathrm{M} \mathrm{S}_{2}$; Amplitude: $50 \mathrm{mV}$; pulse period: $0.2 \mathrm{~s}$; pulse width: $60 \mathrm{~ms}$

Sensitivities for the detection of target SSDNA: The sensitivity of the prepared DNA electrochemical sensor was investigated using differential pulse voltammetric method. The differential peak currents were measured against various concentrations of target ssDNA (Fig. 6). The cathodic peak currents difference was in linear relation with the concentration of target ssDNA in a range from $1.13 \times 10^{-11}-1.13 \times 10^{-9}$ $\mathrm{M}$. The regression equation was found to be $\Delta \mathrm{I}_{\mathrm{pc}}=2.1804 \mu \mathrm{A}$ $+0.6390\left(\mathrm{CS}_{2} / 10^{-9} \mathrm{M}\right) \mu \mathrm{A}$ with a correlation coefficient of 0.9892 . A detection limit of $5.56 \times 10^{-12} \mathrm{M}$ for the target ssDNA was estimated using $3 \sigma$ (where $\sigma$ is the standard deviation of the blank solution, $\mathrm{n}=11$ ).

\section{Conclusion}

Interaction between $\left[\mathrm{Fe}(\text { phen })_{2} \mathrm{IP}\right]^{3+}$ and double-stranded salmon sperm dsDNA was studied using cyclic voltammetry. 


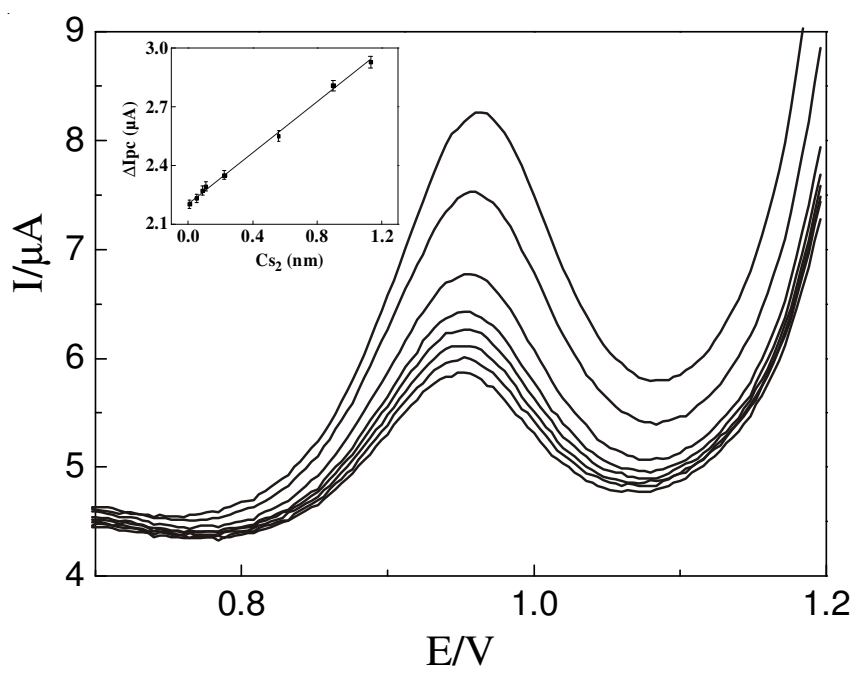

Fig. 6. Relationship curves obtained with different amounts of complementary target DNA

It was shown that $\left[\mathrm{Fe}(\text { phen })_{2} \mathrm{IP}\right]^{3+}$ could be intercalated into double helices of the dsDNA. MWCNTs-COOH/Pt $\mathrm{P}_{\text {nano }}$ were used to prepared a novel covalent electrochemical DNA biosensor for the enhancement of sensitivity of sequencespecific ssDNA detection with a detection limit of $5.56 \times 10^{-12}$ $\mathrm{M}$ and a linear range from $1.13 \times 10^{-11} \mathrm{M}-1.13 \times 10^{-9} \mathrm{M}$.

\section{ACKNOWLEDGEMENTS}

This work was supported by the National Natural Science Foundation of China (No. 21075073) and the Shandong Province Natural Science Foundation of China (No. ZR2010BZ006).

\section{REFERENCES}

1. J. Wang, Anal. Chim. Acta, 63, 469 (2002)

2. B. Kuswandi, S. Tombelli, G. Marazza and M. Mascini, Chimia, 59, 236 (2005).
3. A. Erdem, Talanta, 74, 318 (2007).

4. A. Sassolas, B.D. Leca-Bouvier and L.J. Blum, Chem. Rev, 108, 109 (2008).

5. F. Davis, M.A. Hughes, A.R. Cossins and S.P.J. Higson, Anal. Chem., 79, 1153 (2007).

6. J. Wang, A.N. Kawde and M. Musameh, Analyst, 128, 912 (2003).

7. M.L. Pedano and G.A. Rivas, Electrochem. Commun., 6, 10 (2004).

8. A. Erdem, P. Papakonstantinou and H. Murphy, Anal. Chem., 78, 6656 (2006).

9. J. Wang, G.D. Liu and M.R. Jan, J. Am. Chem. Soc., 126, 3010 (2004).

10. J. Li, H.T. Ng, A. Cassell, W. Fan, H. Chen, Q. Ye, J. Koehne, J. Han and M. Meyyappan, Nano. Lett., 3, 597 (2003).

11. C.L. Xu, J.F Chen, Y. Cui, Q.Y. Han, H. Choo, P.K. Liaw and D.H. Wu, Adv. Eng. Mater, 8, 73 (2006).

12. U. Yogeswaran, S. Thiagarajan and S.M. Chen, Anal Biochem., 365, 122 (2007).

13. S.X. Xu, F.Y. Li and R.Z. Wei, Carbon, 43, 86 (2005).

14. H. Fissan, M.K. Kennedy, T.J. Krinke and F.E. Kruis, J. Nanopart Res., 5, 299 (2003).

15. M.S. Dresselhaus and H.J. Dai, Mater. Res. Soc. Bull., 29, 237 (2004).

16. W.A. Heer, Mater. Res. Soc. Bull., 29, 281 (2004).

17. S.V. Wegner, A. Okesli, P. Chen and C. He, J. Am. Chem. Soc., 129, 3474 (2007).

18. M.R. Gore, V.A. Szalai and P.A. Ropp, Anal. Chem., 75, 6586 (2003).

19. Z.W. Zhu, C. Li and N.Q. Li, Microchem. J., 71, 57 (2002).

20. K. Jiao, Q.J. Li, W. Sun and Z.J. Wang, Electroanalysis, 17, 997 (2005).

21. I.T. Ho, G.H. Lee and W.S. Chung, J. Org. Chem., 72, 2434 (2007).

22. X.M. Li, H.Q. Ju, C.F. Ding and S.S. Zhang, Anal. Chim. Acta, 582, 158 (2007).

23. S.S. Zhang, S.Y. Niu, B. Qu, G.F. Jie, H. Xu and C.F. Ding, J. Inorg. Biochem., 99, 2340 (2005).

24. S.Y. Niu, S.S. Zhang, L. Wang and X.M. Li, J. Electroanal. Chem., 597, 111 (2006).

25. S. Arounaguiri and B.G. Maiya, Inorg. Chem., 35, 4267 (1996).

26. L. Jin and P. Yang, Microchem. J., 58, 144 (1998).

27. S.Y. Niu, S.J. Wang, C. Shi and S.S. Zhang, J. Fluorescence, 18, 227 (2008).

28. A. Harriman, G.R. Millward, P. Neta and M.C. Richoux, J. Phys. Chem., 92, 1286 (1988).

29. S. Hrapovic, Y. Liu, K.B. Male and J.T. Luong, Anal. Chem., 76, 1083 (2004).

30. D.W. Pang and H.D. Abruna, Anal. Chem., 70, 3162 (1998). 